\title{
ETHOS BARROCO'
}

\author{
Armando de Melo Lisboa \\ Universidade Federal de Santa Catarina \\ alisboa@matrix.com.br
}

\section{Resumo}

Este trabalho examina a existência da herança cultural de um ethos barroco próprio na América Latina, o qual, se diferenciando do calvinista-puritano de corte calculista-individualista, se manifestaria nas tradições populares e em inúmeras expressões comunitárias e de solidariedade ainda fortemente presentes tanto no campo quanto nas cidades.

Palavras-chave: Ética. América Latina. Solidariedade.

\section{ETHOS BAROQUE}

\begin{abstract}
This study exams the cultural heritage existence of Latin American's Ethos Baroque, which one is different than a selfish puritan chauvinist, but is present in popular traditions and in various solidarity and communal expressions still strongly present in the cities and inland environments
\end{abstract}

Key words: Ethics. Latin America. Solidarity.

\section{O modo barroco de ser moderno.}

"Nós só seremos civilizados em relação às civilizações o dia em que criarmos o ideal, a orientação brasileira. Então passaremos do mimetismo pra fase da criação. E então seremos universais, porque nacionais" (Mário de Andrade, carta à Carlos Drummond de Andrade)

Em sua controvertida obra $\boldsymbol{O}$ choque das civilizações, Huntington (1997: 52) entende que "a América Latina poderia ser considerada uma subcivilização dentro da civilização ocidental". Entretanto, de forma muito breve, opta por perfilar a Latino-América ao lado das grandes civilizações pois, ainda que "intimamente afiliada ao Ocidente", possui uma tremenda ambiguidade para com esta matriz civilizacional, uma vez que "incorpora, em graus variados, elementos de civilizações indígenas americanas que não se encontram na América do Norte e

\footnotetext{
${ }^{1}$ Esta reflexão pressupõe um imbricamento entre cultura e economia, de modo a evitar os pontos cegos do economicismo classista, que analisa a realidade cultural apenas a partir da categoria "classe", e do fetichismo culturalista que hipostasia acriticamente a categoria "povo". Compartilhamos a compreensão de Dussel (2004: 134), inspirado em Marx, de que "toda cultura é um modo ou um sistema de 'tipos de trabalho'. (...). A poiética material e mítica são pro-dução cultural"
}

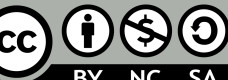


na Europa", além de ser historicamente católica e com fraca influência da cultura protestante.

Apesar de sermos um produto da civilização ocidental, não somos exatamente ocidentais, mas sim o "extremo-ocidente", concisa e lúcida fórmula de Rouquié (1991), retardatário, exótico e multirracial. Enquanto que na Ásia e na África, após séculos de domínio europeu que não mudaram a língua, a religião ou a cultura, o colonizador europeu em geral foi expulso - e somente em meados do séc. XX - nas Américas, emancipadas politicamente desde princípios do séc. XIX, a mestiçagem enraizada de forma permanente no Novo Mundo é uma realidade. Mas, nem por isto estamos a afirmar apologeticamente a ausência de preconceito racial ou a inexistência de barreiras e imensas divisões sociais, de classe ou étnicas. Não há uma fraternidade epidérmica, mas uma elite crioula temerosa de um poder moreno. Também, há que considerar as grandes diferenças entre as diversas nações da AL. Somos um mosaico, mas formado por uma origem comum e amalgamados pelo mesmo destino. Se a contribuição dos elementos indígena e negro é insignificante na Argentina, no Brasil, ainda que o indígena seja amplamente assumido como um dos componentes fundadores da nação, a identidade brasileira não se confunde com indianidade e muito menos com negritude. No México (país "tão longe de Deus e tão perto dos Estados Unidos", afirmava desiludidamente o presidente Porfírio Díaz, 1876-1911), como a presença étnica do componente europeu foi mais restrita, as correntes indigenistas são mais expressivas, enquanto que no Peru, Equador, Guatemala e Bolívia elas já são predominantes.

A questão é compreender a situação da América Latina não segundo outras realidades, mas a partir de si própria, da sua identidade dinâmica e plural, a qual sempre foi e é, necessariamente, construída na relação com outras experiências. A identidade de uma sociedade nunca é perene, pois está sempre em transformação - como afirma Brecht, temos de, "partindo da tradição, levá-la adiante". Num mundo de comunicação instantânea e de profunda interdependência econômica, a realidade é cada vez mais multicultural e híbrida, não existindo culturas "não contaminadas". Aliás, já advertia Braudel (1902:85), reconhecendo os méritos de Mauss, que nunca existiu uma civilização fechada: isto é algo inimaginável, pois não apenas os bens culturais se deslocam com os viajantes, mas também as ideias, os sentimentos, as técnicas, a flora e a fauna. Entende Braudel (1984: 119) que as civilizações são personagens vivas, complexas e contraditórias, fraternas, pacíficas e abertas e, ao mesmo tempo, exclusivas, caprichosas e guerreiras. Simultaneamente móveis, vagabundas e de uma espantosa fixidez. “Como as dunas, bem agarradas a acidentes escondidos no solo: os seus grãos de areia vão, vêm, voam, aglomeram-se à vontade dos ventos, mas, soma imóvel de inumeráveis movimentos, a duna continua lá”. 
A afirmação da identidade, portanto, nunca é absoluta pois encontra-se permanentemente resignificada por um mundo interdependente, além de somente se fazer possível na relação com outras identidades. Neste sentido, "nenhuma identidade pode ser pensada ou estabelecida (...) como um mero ensimesmamento" (QUIJANO, 1992). Não se trata duma divagação abstrata sobre o Ser latino-americano, de buscar uma identidade perdida, mítica, mas de perceber que é a construção do nosso futuro que está em jogo. Há um ser, uma verdade da América? Esta é a questão central sobre a qual se interroga grande parte da nossa filosofia. A pergunta sobre "quem somos?", sobre o nosso modo de ser, sobre nossa sociedade multirracial e mestiçada, morena, se realiza no contexto de nações espoliadas historicamente por um genocídio e etnocídio implacável, brutalmente saqueadas em nome dum falso e hipócrita universalismo, se faz no confronto com o projeto colonialista e imperial ainda vigente. Com lucidez, afirma Octavio Paz (1914-98), prêmio Nobel de Literatura: "a pergunta sobre nós se revela sempre como uma pergunta sobre os outros" (PAZ, 1992: 198), pois sempre somos seres em relação. Neste sentido, a reação contra o colonialismo eurocêntrico, do qual somos fruto, não reivindica o enclausuramento de um comportamento romântico exclusivamente apegado aos próprios costumes e tradições, mas se faz com a consciência de que, "para ser historicamente válida, a autoafirmação dos povos deve confluir para o estuário de todas as altas culturas da humanidade" (RAMOS, 1965: 62). Trata-se duma aspiração ao universal mediatizada pelo local, regional, nacional. Além do mais, "nossa condição de periferia do império nos obriga a ser universais", arremata Boron (2006: 12) num importante prefácio à Fernández Retamar.

Em geral, a expressão barroco denomina a criação arquitetônica-artística difundida a partir das sociedades mediterrâneas e predominante na Europa no século XVII, mas que seguiu reproduzindo-se na periferia do mundo no século XVIII, continuando subterrâneo durante todo o romantismo. Barroco é a irregularidade, a assimetria, a paixão, define Gullar (1988: 219). Uma das suas características é a predominância da linha curva que suplanta a linha reta, acrescenta Gullar (ibid.: 223). "Arte do jogo, arte da fuga e do contraponto" (SANT'ANNA, 1997: 52), o barroco, ao não respeitar a linha ou o plano clássico da unidade (MAFFESOLLI, 1996: 220), nega a fixação de um eixo central, nega a simetria (THEODORO, 1992: 141). Sua apreciação exige o deslocamento e pode ser visto de múltiplos pontos de vista, recusando-se a dar a ninguém uma visão privilegiada (Fuentes, 2001: 201), levando à uma afirmação do pluralismo que inibe o fantasma da unidade e, por conseguinte, sua culminância totalitária.

Em 1543, Copérnico (1473-1543) descobre que a Terra não é o centro do Universo. Galileu (1564-1642), em seguida, afirma que somos apenas um dos planetas que giram em torno 
do Sol. Neste momento em que se dissipam as certezas definitivas, diante do espaço angustiante de um cosmo infinito, o homem da renascença busca algo que o transcenda. Sem poder negar a nova realidade, o espaço barroco cria uma nova fantasia, buscando na ilusão de ótica criar outras perspectivas dentro da realidade. A inquietação e a insegurança dominam o espaço barroco (Gullar, 1988). Face às revelações renascentistas, frente à um universo que começa a se desencantar pelo impulso da dinâmica capitalista então em gênese, o drama barroco busca conjugar as novas e modernas formas de viver, justamente com o seu contrário, as formas antigas e clássicas. Trata-se duma aposta de uma alma atormentada entre a inquietude de um futuro aberto, incerto, mas sedutor, e o desejo de apegar-se ao passado, um esforço absurdo e trágico por conciliar mundos opostos. "Combinação conflitiva de conservadorismo $e$ inconformidade" (ECHEVERRÍA, 1998: 46), a alma barroca se vê atraída tanto pela experiência mística, quanto pela beleza da realidade concreta e humana vislumbrada com o crescente conhecimento renascentista. Daí que é, simultaneamente, sensorialmente carregada e de uma profunda e labiríntica transcendência, sendo corriqueiramente associada à exuberância, a algo voluntariamente imponente, teatral e irreal, levando Adorno afirmar que a arte barroca é uma "decoração absoluta".

Ocorre que no séc. XVII o Barroco surge "sem ninguém saber, surge sem ser chamado de barroco" (GULLAR, 1988: 219). A palavra "barroco" origina-se na língua portuguesa no séc. XVI, designando uma pérola defeituosa, não perfeitamente redonda. Mas é a posteriori que ela vem definir um estilo artístico considerado imperfeito, exagerado, exorbitante. Somente no séc. XVIII se começa a conceituar o barroco, a reconhecê-lo como um estilo, ainda que de forma depreciativa. Rousseau, em 1764 no seu Dicionário da Música, empregou o conceito de barroco para definir um estilo musical "cuja harmonia é confusa, carregada de modulações e dissonâncias" (apud. OROZCO, 1981: 28). Em 1771 o "Dicionário de Trabalhos", editado na França, registra como "barroco" o estilo de quadros e figuras "onde as regras das proporções não são observadas, onde tudo é representado segundo o capricho do artista" (apud SANT'ANNA, 1997: 29). Mas quando em 1925 Benedetto Croce dizia que o Barroco não apenas era feio, era o "não estilo" (ibid., 30), uma "varietà del brutto" (apud ROUANET, 1984: 26), neste momento esta opinião "já era uma extravagância" (ROUANET, 1984: 26), pois a concepção do barroco já tinha mudado profundamente. Ele perde sua conotação de arte pervertida, decadente a partir do livro Renascença e barroco, publicado em alemão em 1888 por Heinrich Wölfflin, discípulo de Burckhardt. Nesta obra pioneira o termo barroco surge como conceito crítico-estético para designar positivamente a arte do séc. XVII como um estilo próprio, originando nos 40 anos subsequentes um interesse apaixonado e até avassalador pelo 
barroco, cujo auge, para Rouanet, encontra-se com o espanhol Eugenio d'Ors, autor de $\boldsymbol{O}$ barroco (1923).

Após um longo tempo olhado com desdém e dado como ultrapassado, irrompe no princípio do séc. XX o movimento barroquista, tornando-se uma moda aplicar o termo "barroco" fora do seu campo original. Não se restringindo a simplesmente designar um estilo arquitetônico, escultórico ou literário, "passou a abranger um vasto complexo de ideias mais ou menos vagas acerca da essência da civilização do século XVII" (HUIZINGA, 1938/1996: 202). No Brasil o barroco ressurge das névoas do esquecimento através de Mário de Andrade (1893-1945) e dos mesmos protagonistas da Semana de Arte Moderna (de 1922) que em 1924 fazem uma viagem pelas cidades históricas de Minas, redescobrindo o Brasil.

Em 1942, O. Carpeaux (1900-78) confirmava a "verdadeira revalorização do barroco", compreendido não mais como um sinônimo de "decadência nas artes", mas agora como um "sistema de civilização", "uma atualidade viva" (1990: 7). Pontuando elementos da "sociologia um pouco fantástica do barroco" (1990: 32), acentuou Carpeaux que uma das suas principais expressões estaria no Estado barroco e sua tragédia. Ao apresentar e debater a "teoria política do barroco" (1990: 21), mostrando os fundamentos e conflitos da "política barroca", antecipou parte do debate contemporâneo. Em verdade, há uma enorme variedade de barrocos. Mesmo reconhecendo que "a alma da vida barroca é de substância latina, mediterrânea", para Carpeaux o barroco não se limitava à cultura católica, a ser uma arte da Contrarreforma, pois houve também um barroco protestante. Aliás, foi na Alemanha que se deu a grande voga de reabilitação do barroco, contexto onde se insere a primeira grande reflexão de W. Benjamin (1892-1940), A origem do drama barroco alemão (1925).

O barroco é uma das formas históricas do ethos moderno, ou seja, um princípio de organização da vida social. O uso do conceito de barroco não restringido apenas a qualificar um estilo artístico-cultural, mas como um conceito de época (MARAVALL, 1975/1997: 45) ou modo de vida, "é uma tendência tão velha como a idéia mesma de barroco" (ECHEVERRÍA, 1998: 11). Munford (1895-1990), em 1938, preferia usar o barroco "como termo de descrição social, não de limitada referência arquitetônica". Trata-se de uma "mentalidade", um "tempo" e um "espaço" opostos ao pensamento abstrato cartesiano e capitalista (MUNFORD, 1961:102103). Para Munford (1961: 88), o conceito de barroco contém dois elementos contraditórios: o lado matemático, mercantil e metódico, e o lado sensual, rebelde e extravagante. A força do barroco para Munford é tal, que este considera as formas renascentistas como "protobarrocas", e até mesmo o romantismo uma fase do "capricho barroco", estando destinado a perdurar durante o século XIX (1965: 452). 
Já Maravall (1911-86), em seu clássico A cultura do barroco (1975/1997: 59), afirmava que "não se pode abstrair o barroco como um período da arte", pois "afeta e pertence ao âmbito total da história social (...). Dizer barroco artístico significa dizer cultura barroca contemplada em seu sistema do ponto de vista da arte". Para ele, em grande parte o desenvolvimento do barroco no século XVII decorre da prolongada crise econômico-social, retratada especialmente na decadência dos países ibéricos neste período. As guerras e o "crescente empobrecimento das massas criam um sentimento de ameaça e de instabilidade (...) que estão na base da gesticulação dramática" do barroco ibérico (1997: 71, 45).

Distinguindo entre viver em e com o capitalismo, de viver por e para ele, entende B. Echeverría o Barroco como uma das diferentes possibilidades que se oferecem para viver dentro do capitalismo, como um ethos que caracteriza um dos tipos históricos de modernidade. Para Echeverría, a atualidade do barroco deriva da profunda crise da versão puritana e norte-europeia da modernidade. Nesta versão, a modernidade capitalista é cega para a complementaridade contraditória entre a reprodução da riqueza (lógica de valorização do valor ou de acumulação de capital) e a do processo de trabalho e desfrute/consumo (ou do valor de uso), exigindo que se rompa com a ambiguidade do mundo e que se sacrifique a segunda dinâmica, submetendo-a à primeira. $\mathrm{O}$ ethos barroco é uma negação desta incondicionalidade e uma decisão pelo terceiro excluído: tertium datur! A busca barroca do terceiro excluído não sacrifica o valor de uso, mas tampouco se rebela contra a valorização do valor, pois toma partido pelos dois contrários. “Eleger a 'terceira possibilidade', a que não tem lugar no mundo estabelecido, traz consigo um 'viver outro mundo dentro deste mundo' ”, (1998: 176).

Sob uma outra perspectiva, também se barroquisa Maffesoli, uma das principais expressões duma assumida postura pós-moderna celebratória que relativiza o projeto emancipatório iluminista. A vida social contemporânea está em vias de barroquização devido à turbulenta fase de transição que hoje vivemos, com sua caótica socialidade, relativismo ideológico, policulturalismo crescente e diversificação dos modos de vida com que estamos confrontados. Diante duma realidade cada vez mais ambígua, o barroco é bastante "pertinente para descrever o caldo de cultura multiforme e estruturalmente heterogêneo constitutivo de nossas sociedades. Maffesoli eleva o barroco à condição de "arquétipo", sendo uma verdadeira "bacia semântica" para a qual confluem as mais diferentes correntes que vão constituir a "unicidade múltipla do tempo barroco". A lógica própria da "sensibilidade barroca" é a do "tertium datur", é a da inclusão que mantém "juntos elementos perfeitamente heterogêneos" (1996:189-219; 1998: 70).

Ainda que não seja advindo da tradição cristã, Maffesoli percebe as múltiplas 
convergências do pós-modernismo com o passado pré-moderno, pois entende que um pensamento orgânico, tal como exercido nas sociedades tradicionais, está a renascer contemporaneamente, como num novo renascimento - agora não mais da cultura clássica grega, mas da cultura católica. Isto o leva a reconhecer que "mesmo no cristianismo (...) encontramos de modo recorrente bolsões de resistência" que se empenham em manter unidas a ética e a estética, como o franciscanismo e a sensibilidade barroca (1996: 17). Para Maffesoli o espírito barroco "é totalmente místico", acentua, correspondendo a um "realismo místico", a um mundo que se reencanta (ibid.: 224, 222).

A obra de Maffesoli está eivada de categorias religiosas, recorrendo a elas profusamente como que se rendendo à teologia escolástica e aos místicos cristãos: atitude apofática, participação mística, comunhão dos santos, inefável, unicidade, evitação. Ele é atraído pelo mistério da encarnação de Cristo, vislumbrando no mito cristão do "logos feito carne" uma profunda expressão da conjunção de elementos díspares mas empiricamente vividos como complementares (1998: 184). Aliás, reconhece que é próprio dos místicos barrocos a interação da sensibilidade com a espiritualidade (ibid.: 197), o que o leva a afirmar que "o cristianismo enquanto civilização junta-se, pelo menos em parte, à harmonia grega, admitindo a união do sensível e do espírito como caminho em direção à divindade. O barroco, em seu apogeu, só fará aumentar até suas últimas consequências um tal sensualismo" (1996: 81). Assim sendo, ambiciona Maffesoli alargar a cama de Procusto do pensamento moderno, forjando um conhecimento orgânico, empático, sensual, um "saber de tipo Sul" que não violenta mas permite uma abordagem respeitosa dos fenômenos sociais. Entende que este esforço está grávido de importância face a saturação e "a relativização dos valores do Norte - dominados pelo produtivismo, pelo ativismo, pela irritação frente ao drama" (1998: 147).

Embora prefira falar em barroco como metáfora de uma forma de subjetividade e de sociabilidade do que como expressão de um ethos cultural, Boaventura Santos acaba reconhecendo que "o barroco é, essencialmente, um fenômeno latino e mediterrânico, uma forma excêntrica de modernidade" (2000: 357), e que se desenvolve especialmente no Sul do Sul europeu: na América Latina. Foi o fato da AL ter sido colonizada por centros coloniais débeis que permitiu o desenvolvimento da cultura barroca nesta região. Santos apresenta o barroco como um dos principais guias emancipatórios para o período de transição paradigmática, pois percebe a subjetividade barroca como perfeitamente compatível com o paradigma emergente, dado seu caráter aberto e inacabado. Conclui Santos que a barroca subjetividade emotiva e apaixonada é "uma subjetividade do Sul”, favorecendo as mestiçagens e relações de poder partilhadas. 


\section{A matriz católica-ibérica da primeira modernidade}

O reconhecimento do ethos barroco obriga a debater o papel civilizatório da matriz católica-ibérica, como inclusive contemporaneamente o fazem, inter allia, Barboza Filho, Braudel, Chacon, Daly, B. Echeverría, Löwy, Morse (1922-2001) e Huntington. Entre os séculos XV e XVII a península ibérica viveu seus "séculos de ouro", tendo peso econômicopolítico-militar e cultural determinante na história mundial. Em geral, duas antagônicas leituras são feitas sobre este período. De um lado, a Ibéria do clichê da Lenda Negra, cruel, da Contrarreforma obscurantista. Do outro, a edificação na Ibéria de uma verdadeira variante da civilização ocidental, forjadora de um horizonte que moldava o novo mundo com premissas antagônicas e competitivas em relação à perspectiva anglo-saxã. $\mathrm{O}$ enigma da Ibéria foi bem captado por Barboza Filho (2000: 32): “a Ibéria dos Séculos de Ouro e dos séculos anteriores é uma vertigem, um labirinto, uma polissemia constante e um enigma renovado. (...). Ora ela é responsabilizada pelo atraso material e cultural de Espanha e Portugal, ora transmuta-se em fonte de sentido para restaurações de corte nacional e identitário (...)”.

Braudel (1947/1984), em sua ampla e monumental reflexão sobre o mundo mediterrâneo no século XVI, distingue entre a civilização "latina" ou "barroca" (que se irradia com base no império espiritual italiano e na força temporal de Espanha e Portugal), e a do Norte europeu e protestante ${ }^{2}$. Especialmente a Ibéria no tempo do esplendor dos reis católicos, a "civilização ibérica" é, para Braudel, "uma variedade particular da civilização do Ocidente", "a última civilização ecumênica proposta e imposta à Europa", a qual poderia ser mais apropriadamente designada de "jesuíta" (ibid.:185-193). Sugere-se aqui que a ponta da Europa que avança sobre o Atlântico é possuidora de um núcleo de princípios que não podem ser descartados simplesmente como um reflexo atrasado do moderno mas devem ser avaliados como uma weltanschaung especial, uma variante civilizacional.

Sob forte e herética influência erasmiana ${ }^{3}$ - é bom recordar que o humanismo herasmiano é, no entender de Jaime Cortesão, a culminância do renascimento greco-latino

\footnotetext{
${ }^{2}$ Braudel acompanha e amplia as teses de Jacob Burckhardt em A cultura do renascimento na Itália (Companhia das Letras, 1991), publicada originalmente em alemão em 1867.

${ }^{3} \mathrm{O}$ erasmismo, que tanto repudiava o cisma quanto exigia uma reforma no catolicismo, declina rapidamente a partir de 1563, quando encerra-se o Concílio de Trento e se altera profundamente o clima espiritual na península Ibérica. As obras de Erasmo entram no Índex já em 1554, e a Inquisição tem uma rigorosa postura erasmófoba, perseguindo duramente aqueles que representavam o espírito erasmita, a ponto de 50 anos após o nome e o pensamento de Erasmo praticamente desaparecem, sendo que seus últimos reflexos na Espanha se encontram em Cervantes (cf. Bataillon, cap. XIII - "O erasmismo condenado"; cap. XIV - "Últimos reflexos de Erasmo").
} 
(COSTA, 1967:25) - o renascimento ibérico foi um renascimento católico místico (Inácio de Loyola, 1491-1556; Teresa d'Ávila, 1515-82; Juan de la Cruz, 1542-91) e neotomista ${ }^{4}$. Séculos antes de Maffesoli reinventar a "razão sensível", os trabalhos do dominicano Francisco de Vitória (1480-1546), do humanista Juan Luis Vives (1492-1540), dos jesuítas Luis Molina (1535-1600), Francisco Suárez (1548-1617) e outros que viviam entre o quadrilátero formado pelas universidades de Salamanca (criada em 1218), Coimbra (1290), Évora e Alcalá de Henares, forjaram uma "escolástica barroca" (conf. Maritain) que buscava o "advento de uma modernidade orgânica, não a desintegrada que acabou por se impor" (CHACON, 1998: 148), fundada sobre uma sapientia cordis, uma sabedoria do coração, sobre um conhecimento afetivo, místico 5 .

A cultura ocidental, especialmente a ibérica, viveu então uma época gloriosa em termos plásticos, pictóricos e arquitetônicos, seja na literatura (para Carpeaux, 1960: 683, o período entre 1580 e 1680 foi "o mais rico de todos na história da literatura universal"), na poesia, na pintura, na música ou no teatro: Miguel de Cervantes, 1547-1616; Luis de Camões, 1524-80; William Shakespeare, 1564-1616; Francisco Quevedo, 1580-1645; Luis de Gôngora, 15611627; El Greco, 1541-1614; Caravaggio, 1573-1610; Peter Rubens, 1577-16486; Diego Velásquez, 1599-1660; Lope de Veja, 1562-1635; Pedro Calderón de la Barca, SJ, 1600-81. De modo geral, o barroco está associado à fase de decadência econômico-político-militar do mundo ibérico, ou seja, ele ascende no momento em que ocorre a derrota da invencível armada espanhola em 1588, o que possibilitou que França, Inglaterra e Holanda passassem a rivalizar com a Espanha, retirando dela a hegemonia internacional que então desfrutava. Desta perspectiva o barroco seria decorrente do crescente empobrecimento das massas e do sentimento de insegurança social, expressão do lamento pelos anos dourados ibéricos, dramatização da dor da perda. A alma barroca vê as muralhas desmoronarem, mas não se desespera, pois sabe que la vida es frenesí, sueño, ilusión. O barroco se afirma como a capacidade humanista de reconciliar os contrários, incorporando tanto a claridade da renascença quanto os aspectos escuros da vida: dor, morte e sofrimento. Entretanto, ressalve-se que é

\footnotetext{
${ }^{4}$ Consultamos as extensas e minuciosas avaliações e revisões sobre a escolástica progressista ibérica feitas seja globalmente, seja desde a filosofia e do pensamento político, econômico, semiótico e do direito internacional, por Barboza Filho, Chacon, Courtine, Echeverría, Lefort, Lima, Morse, Naredo, Todorov (analisa Las Casas, Sahagún e outros do ponto de vista semiológico), Schneewind, Schumpeter e Skinner.

${ }^{5}$ Obviamente tanto não há uma unidade plena entre estes pensadores, quanto também não refletem a posição oficial de Roma na época, a não ser em alguns aspectos, sendo que inclusive muitos chegaram a sofrer com a inquisição e tiveram suas obras incluídas no índex.

${ }^{6}$ Rubens, pintor flamengo e figura maior da arte barroca do Norte da Europa, educou-se na Itália entre 1600 e 1608, tornando-se a partir de 1609 pintor das cortes do arquiduque Alberto e da infanta Isabela, regentes espanhóis da Holanda.
} 
demasiadamente arriscado ligar "estreitamente as criações do espírito, isto é, a mais livre atividade que se possa imaginar, aos acontecimentos da história e à vida econômica ... De fato, as relações entre literatura e sociedade são praticamente indefiníveis" (Henry Peyre, apud Löwy; Sayre, 1995: 20) ${ }^{7}$. Tanto seus elementos já estavam presentes ao longo de todo o séc. XVI (não se pode ignorar que a pré-história do barroco se enraíza na renascença), quanto de fato o barroco não se restringe à Ibéria.

O fato da Ibéria tropeçar com a Ameríndia irá inaugurar a própria modernidade, possibilitando que a Europa se firmasse como centro de uma história mundial. Esta é a tese de Oswald de Andrade em 1945, o qual, sustentando-se em Sombart (1863-1941) - este declarou, em $\boldsymbol{O}$ Burguês (1913), que sem as jazidas americanas "não teríamos o homem econômico moderno" (apud. ANDRADE, 1990: 63) - entendia que as descobertas geográficas mudaram a face da terra por terem rompido "o status quo econômico do Ocidente e dado a preponderância a povos que antes não podiam progredir com seus próprios recursos" (ibid.). A modernidade, argumenta Dussel (1993: 7), só é possível pela sua relação dialética com o elemento nãoeuropeu: por isto "a periferia é parte de sua própria definição". Dussel sustenta a tese de que a superioridade europeia sobre o mundo otomano-muçulmano, a Índia e a China, não decorre de suas possíveis e excepcionais características internas, mas da vantagem comparativa determinante adquirida com a anexação da Ameríndia. O tráfico negreiro e a economia com base na escravidão na América foram um "pedestal de superexploração" (NEGRI; HARDT, 2001: 139) relativamente estável que deu gênese ao capitalismo europeu já na forma de sistema mundial. Define Dussel (2004: 139) que a invenção do sistema colonial e sua brutal espoliação ao longo dos séculos, progressivamente fará pender a balança do poder em favor da Europa, até então periférica. A Ameríndia é, portanto, o fato originante da modernidade, constitutivo da sua primeira definição. Entretanto, tanto Hegel (1770-1831) quanto Habermas descartam o papel da Ibéria da definição originária da Modernidade, e, se esta está fora, muito mais está a América Latina (DUSSEL, 1993: 23).

Demonstra Dussel (2004: 140) que a primeira modernidade (de 1492 à 1630) é ibérica, porém com matizes muçulmanos, embebidos com elementos do Renascimento italiano e "pela cultura barroca jesuítica". Apesar do pensamento produzido pela primeira modernidade hispânica, renascentista e humanista ser da maior importância, ele foi descartado pela filosofia moderna (DUSSEL, 2000: 60). Ocorre dentro do pensamento ocidental clássico e

\footnotetext{
7 "A relação entre sociedade e literatura não é de causa e efeito. O vínculo entre uma e outra é, ao mesmo tempo, necessário, contraditório e imprevisível. A literatura expressa a sociedade, ao expressá-la, a muda, a contradiz ou a nega. Ao retratá-la, a inventa; ao inventá-la, a revela" (Paz, 1984: 27).
} 
contemporâneo um esquecimento do papel fundante da periferia para ascensão do sistemamundo europeu, revelando o caráter pseudo-universal, provinciano e eurocêntrico deste, bem como sua falácia desenvolvimentista. Em sua ampla avaliação da Ética da Libertação na idade da globalização e da exclusão, Dussel (2000: 64) situa a Ameríndia como parte da modernidade desde o primeiro momento, o da conquista e colonização: "o mundo mestiço na América Latina é o único que tem tanta idade quanto a modernidade".

Antecipando Hobbes (1588-1679), Locke (1632-1704) e Rousseau (1712-78), os neotomistas ibéricos foram precursores das teorias do Estado moderno e do direito internacional, sendo que os dominicanos Montesinos (1475-1545) ${ }^{8}$, B. de Las Casas (14741566), Vitória e Suárez, SJ, fizeram uma das primeiras defesas dos direitos individuais e da liberdade da história. Entende Silva Filho (2002: 321) que Las Casas antecipa muitas considerações libertárias da teoria política moderna. Neste momento, séc. XVI, surge na Espanha a questão ética fundamental: que direito tem o europeu de ocupar e dominar os povos americanos? Registra Dussel (2000: 60) que a segunda modernidade, no séc. XVII, já não teve escrúpulos de consciência, e o eurocentrismo não será mais posto em questão até o final do séc. XX. A resposta de Las Casas, na avaliação de Dussel (2000: 61), não permite subterfúgios, demonstrando que "a constituição do sistema-mundo como expansão européia na Ameríndia não tem direito algum; é uma violência injusta, ilegítima e não pode ter nenhuma validade ética".

$\mathrm{O}$ argumento de Vitória, utilizado por las Casas no debate, aparentemente absurdo, mas célebre e crucial, sobre o estatuto ontológico dos habitantes recém encontrados nas novas terras", é claro e direto: "mesmo que a fé cristã tenha sido enunciada aos bárbaros com argumentos completos e ainda assim eles a tenham recusado, isso não constitui razão para fazer-lhes guerra e despojá-los de seus bens" (apud Skinner, 1996: 446). Na rigorosa avaliação de Todorov, las Casas evoluirá neste debate para as radicais posições perspectivistas e para uma posição de um amor pelo outro "não mais assimilacionista" tão subversiva que "dá um passo em direção ao abandono do próprio discurso religioso" (TODOROV, 1993: 188). Las Casas chega a defender que o rei da Espanha renuncie às suas possessões ultramarinas e, no limite, faça guerra aos próprios conquistadores espanhóis: “o verdadeiro remédio para todos esses

\footnotetext{
${ }^{8}$ Montesinos, ao proferir os célebres sermões de 1511 condenando a escravidão dos índios, considerado como o primeiro manifesto anticolonialista da América (Mires, 1991: 69), precipita o conflito aberto entre o projeto missionário-indigenista e o mercantilista-militar. Junto com Las Casas, são considerados os primeiros defensores dos direitos humanos na América Latina (conf. Silva Filho, 2002: 299).

${ }^{9}$ Todavia, registre-se que o mundo anglófono não permitiu semelhante debate, "o primeiro debate moderno $e$ amadurecido sobre os direitos humanos, algo que jamais parece haver preocupado os outros poderes coloniais" (Fuentes, 2001: 132).
} 
males, que (...) os reis de Castela, por preceito divino, devem aplicar, inclusive pela guerra, se não puderem fazê-lo pacificamente, e ainda que tivessem de arriscar todos os bens temporais que possuem na Índias, é livrar os índios do poder diabólico ao qual estão submetidos, devolver-lhes a liberdade original e restabelecer em suas soberanias todos os reis e senhores naturais" (apud Todorov, 1993: 191). E, numa inversão completa, aponta o índio como o verdadeiro evangelizador: "a verdade é que muitíssimos destes homens podem governar-nos já na vida monástica, na vida econômica e também na vida política, podendo também ensinarnos e reduzir-nos aos bons costumes" (Las Casas, De único modo 1537, apud SUESS, 1991: 112).

Las Casas não foi uma voz profética isolada, mas o porta-voz de uma experiência eclesial baseada no evangelho que proclamava "Deus ou o ouro. Ninguém pode servir a dois senhores", e que inclusive entusiasmava alguns teólogos europeus. Skinner (1996: 450), em seu grande painel sobre As fundações do pensamento político moderno, reconhece que "há um certo grau de verdade" nas afirmações que creditam os filósofos tomistas ibéricos entre "os principais fundadores do pensamento constitucionalista e até do pensamento democrático". Conclui ainda que este legado tomista funcionou como o canal pelo qual "a aplicação do contrato social à análise da obrigação política pôde exercer a mais decisiva influência" (ibid.). Vitória, por exemplo, nega o poder coercitivo absoluto papal ao mostrar que "o poder temporal não depende em absoluto do Papa" (apud, SKINNER, 1996: 451), e que é "indubitável e manifestamente falso" afirmar que "o Papa possua autoridade temporal direta e jurisdição sobre o mundo inteiro". Para Skinner (1996: 440), Suárez repudia a tradicional tese católica e amplamente aceita então na Europa de que "o poder político é conferido por Deus a um determinado príncipe, e deve sempre ter continuidade, por um processo de sucessão hereditária, numa determinada pessoa". Replica Suárez que essa conclusão pressupõe o esquecimento de que "é essencial que o primeiro possuidor tenha derivado seu poder supremo diretamente da república", uma vez que "o poder civil sob qualquer forma, para que seja justo e legítimo, deve resultar de uma concessão direta ou indireta da comunidade, não podendo de outro modo ser mantido com legitimidade".

Mas há importantes diferenças entre estes neotomistas e o pensamento político de Hobbes e Locke: para aqueles o Estado nunca terá no indivíduo seu ponto de partida, pois os homens não viviam primitivamente como indivíduos livres e isolados que mais tarde se associariam por um contrato. Afirmam os ibéricos que a sociedade política estaria ancorada numa sociabilidade intrínseca dos homens: tanto "o homem foi criado livre" (VITÓRIA, apud SKINNER, 1996: 433), quanto "é fato essencial ao homem jamais viver sozinho" (ibid.: 434), 
o que é reafirmado ainda mais claramente por Suárez: "o homem é por natureza um animal social" (ibid: 435). Vitória, antecipando e negando a célebre hipótese hobesiana, afirma: "Non enim homini homo lupus est, ut ait Ovidius sed homo" [Na verdade, o homem não é o lobo do homem, como disse Ovídio, mas homem] (apud BARBOZA FILHO, 2000: 297). Para os pensadores católicos, na límpida avaliação de Morse (1988: 61), se o Estado é reconhecido pelo seu poder coercitivo tanto por Vitória quanto por Hobbes, "para Vitória esse poder deve ser exercido para a realização do bem comum e a administração da justiça segundo os princípios cristãos. O pacto político de Hobbes foi adotado por medo antes que por um espírito de auto realização comunal, e a injustiça é definida no Leviathan como 'nada mais que o não cumprimento do pacto' ". Morse irá ressaltar as diferenças epistemológicas, pois enquanto o método empírico refletia uma racionalidade dessacralizada, utilitária e atomista, os ibéricos adotaram uma abordagem marcadamente holista.

Suárez declara, fazendo frente à Maquiavel (1469-1535), que "se o rei converte seu justo poder em tirania" tornando seu governo "manifestamente pernicioso para toda a república", por conseguinte será justo "que a comunidade faça uso de seu poder natural para defender-se" (apud SKINNER, 1996: 454). Reiteradamente defende Suárez o "poder de depor um rei", mas sempre quando "um método de autodefesa" e para preservar a república. Diante da arbitrariedade do príncipe, antepõe que: "si leux esset injusta, non tenetur populus eam acceptare, quia injusta lex non est lex" [se a lei é injusta, o povo não está obrigado a aceitá-la, porque uma lei injusta não é lei] (SUÁREZ, apud BARBOZA FILHO, 2000: 306). Daí que Chacon, apaixonadamente, veja os semeadores da renovação escolástica como defensores dos direitos civis e humanos, dos oprimidos, do poder vindo de Deus através do povo, da soberania popular e do direito do povo à revolução. Completa Leopold von Ranke, expressando de forma mais sintética e serena as paradoxais ideias destes padres: “Os jesuítas não tiveram grande dificuldade em fazer derivar do povo o poder real. Construíram um sistema fundindo sua doutrina da supremacia do papa com a doutrina da soberania popular. (...). Estranha união de pretensões eclesiásticas e de ideias democráticas, de liberdade absoluta e de submissão completa, contraditórias em si mesmas ...”( apud CHACON, 1998: 74).

A "Escola de Salamanca"10 antecipou grande parte da moderna teoria econômica, a ponto de Schumpeter, 1964: 105-186, 380, registrar: "está tudo nos Escolásticos". Estes "últimos escolásticos" se consagraram a justificar a prática usurária e comercial, mas sem

\footnotetext{
${ }^{10}$ Além de Vitória, considerado fundador desta escola, inclui-se também Domingo de Soto (1494-1560), Martin de Azpilicueta, Tomás de Mercado (1530-75), Luis de Molina (1535-1601) e os jesuítas Léssio ou Leonardo de Leys (1554-1623) e Juan de Lugo (1583-1660). Nem todos lecionaram em Salamanca, mas compartiam o clima intelectual daquela universidade.
} 
despojá-la dum sentido moral, da centralidade da justiça, e sua destinação social. Se já é bastante aceito, em particular, o papel do Fr. T. de Mercado como precursor da teoria monetária, salienta Chacon (1998: 159) que entre as influências do renascimento católico ibérico do séc. XVI sobre o iluminismo do séc. XVIII encontra-se a marca da Suma de tratos y contratos (1569) de Mercado sobre Francis Hutcheson, mestre de A. Smith. Na objetiva avaliação de Tawney, que recua sua reflexão para Tomás de Aquino e lembrando que o papado era "a maior instituição financeira da Idade Média", o propósito das especulações econômicas escolásticas era eminentemente prático e visava solucionar os problemas e reconciliar as novas relações que brotaram da expansão econômica, com a moralidade cristã. "Vistos pela posteridade como reacionários (...) em sua própria época foram os pioneiros de um movimento intelectual liberal. Levantando o peso de fórmulas antiquadas, desobstruíram um lugar dentro da estrutura rígida da autoridade religiosa para interesses econômicos novos e móveis (...). O pensamento mercantilista dos séculos posteriores tem uma considerável dívida às discussões escolásticas sobre dinheiro, preços e juros" (TAWNEY, 1922/1971: 46). Diante das ideias de que "o trabalho é necessário e honroso", e de que apenas quando o mercador "procura o ganho não como um fim, mas como o salário de seu trabalho" é que sua remuneração não seria vista como turpe lucrum, Tawney (1971: 50) irá concluir que a verdadeira descendência das doutrinas escolásticas "é a teoria do valor trabalho. O último dos escolásticos foi Karl Marx" (grifo nosso).

Outrossim, é preciso perceber que a renovação espiritual Católica na Espanha antecedeu a revolta luterana (deflagrada em 1517) e o Concílio de Trento, como registra amplamente Bataillon ao analisar a pré-reforma do cardeal Jiménez de Cisneros impactando diretamente as ordens monásticas. Casos típicos e exemplares da renovação religiosa são o de santa Teresa e de Inácio de Loyola. Loyola, em particular, desde sua conversão em 1521 à fundação da Companhia de Jesus em 1539, estudou em Alcalá, Salamanca e Paris, onde embebeu-se do humanismo herasmita a ponto de ser preso pela inquisição conduzida pelos ortodoxos dominicanos. Estas influências humanistas que renovaram o pensamento escolástico e moderno "sobreviveram mesmo depois de feita a 'escolha' da Contrarreforma" (MORSE, 1988: 55). Chacon (1998), por exemplo, enxerga no "Ratio Studiorum” jesuítica, promulgada em 1599, a presença da tão procurada nova paidea integradora das fragmentações da modernidade.

Sem dúvida que se faz necessário revisar a imagem iluminista francesa sobre o caráter puramente reacionário dos jesuítas e da Igreja Católica pré e pós-tridentina (Echeverría, 1998: 
$65)^{11}$. Echeverría conclui que estas correntes buscavam então "construir uma modernidade própria, religiosa, (...) alternativa à modernidade individualista abstrata, que girava em torno da vitalidade do capital" (ibid.: 49). O projeto jesuítico de modernização católica do mundo implicava na restauração da Igreja romana como meio central de socialização e como entidade política. Com o clima anticlerical próprio do século XVIII, a reação iluminista concentrou-se num antijesuitismo, face a hegemonia intelectual-política destes dentro do catolicismo. Os seguidores de Inácio de Loyola representavam então uma ameaça, a qual foi "vista pelo despotismo ilustrado como principal inimigo a vencer" (ibid.: 73), levando à expulsão da Companhia de Jesus das terras latino-americanas e selando o futuro das repúblicas guaranis. Esta derrota da utopia católica naquele momento em experimentação no Ocidente é apenas mais um capítulo da história do assenso de uma modernidade capitalista que busca configurar o mundo à imagem e semelhança do capital.

A obra magna de Weber, A ética protestante e o espírito do Capitalismo, insinua que o ethos católico seria anticapitalista. Ainda que Weber não tenha realizado um estudo sistemático das relações entre o catolicismo e o espírito capitalista, entende Löwy (2000: 34) que há um evidente subtexto: "a Igreja católica é um ambiente muito menos favorável - se não completamente hostil - ao desenvolvimento do capitalismo que as seitas calvinistas e metodistas". Em sua avaliação, constata com espanto que praticamente não existe "qualquer tratamento substancial dessa questão na imensa literatura escrita sobre a tese weberiana que foi publicada nos últimos oitenta anos" (2000: 35) ${ }^{12}$. Indica Löwy que Weber somente vai tratar brevemente da questão em obras posteriores, acentuando apenas a oposição da Igreja à natureza fria e impessoal das relações capitalistas ${ }^{13}$.

Em verdade, como constatamos com os escolásticos ibéricos, não há uma incompatibilidade entre catolicismo e capitalismo. Tampouco há uma essência capitalista no calvinismo, demonstra Lefort. Importa vislumbrar que entre o mundo católico e o da Reforma existem diferenças profundas, pois enquanto o catolicismo acentua a dimensão comunitária e sacramental, o espírito protestante preconiza o diálogo direto do indivíduo com deus, sem

\footnotetext{
${ }^{11}$ Marcel Bataillon, em Erasmo e Espanha (1937/1996) foi precursor em reavaliar o papel da Contrarreforma. Braudel, assim como Maravall (1997: 58), também viam impropriedades nesta denominação. Braudel (1984: 38; $128 ; 130)$ referiu-se a "esse poderoso movimento da Reforma católica a que chamamos abusivamente a Contrarreforma. (...) Aquilo que se chama a Contrarreforma é, se se pretender, a sua Reforma", ou seja " é uma renovação cristã".

${ }^{12}$ Apesar desta taxativa afirmação, Chacon (1998: 169) indica que Wolfgang Schluchter (em Max Weber Sicht des okzidentalen Christentums (Suhrkamp, Frankfurt, 1988) reuniu weberianos para uma discussão a propósito do catolicismo, bem como também quanto ao islamismo (in Max Webers Sicht des Islams, mesma editora e local, 1987).

${ }^{13}$ Mesmo abordando extensamente sobre "Sociologia da religião", maior capítulo da póstuma obra Economia e Sociedade, Weber não discute sobre o assunto.
} 
intermediários, ajustando-se melhor com a revolução econômica em curso. Enquanto que o catolicismo ("que durante séculos foi a linguagem de camadas sociais dominantes que não eram burguesas" - Lefort, 1979: 139) expressava uma mentalidade onde o espiritual e o material estavam fundidos, uma realidade onde a economia estava amarrada em relações pessoais, o protestantismo, ao interiorizar sua oposição ao catolicismo, acaba se comunicando otimamente com as rápidas transformações econômicas decorrentes das grandes descobertas e da imensa transferência de capitais para a Europa e que levavam ao desmoronamento da sociedade feudal e ao desenvolvimento da burguesia. $\mathrm{O}$ ato constitutivo e revolucionário do capitalismo foi a separação entre os negócios e o lar, a separação entre os produtores e as fontes de sobrevivência. Isto libertou as ações voltadas para o lucro (e também às voltadas à sobrevivência) da teia de laços morais e emocionais, da família e da vizinhança (Bauman). Como o protestantismo permitiu que a secularização da economia e da política se efetuasse no seio mesmo da religião, ele foi funcional à revolução econômica, possibilitando a formação da identidade burguesa de forma a diferenciá-la claramente das antigas elites e do holístico modo de viver feudal, ainda que o catolicismo não lhe fosse tão hostil.

Se para alguns o neotomismo favorece uma sociedade autoritária e corporativista, outros, como Morse (1992: 138), entendem que a herança do tomismo não é apenas hierarquismo e corporativismo, ainda que esta seja a tendência principal da doutrina oficial católica, mas também um vetor orientado de tipo comunitário-socializante, como se vislumbra nas estratégias de libertação das Comunidades Eclesiais de Base. Não custa recordar que o cristianismo, enquanto instituição, sempre foi atravessado, em toda sua história, pelo conflito entre os que, mais coerentes com sua tradição primordial, defendiam o princípio comunitário, e as forças que impunham o princípio hierárquico na mesma medida em que surgia uma civilização de verniz "cristão" (HOORNAERT, 1991: 90).

\section{América barroca. Utopia e ficção.}

"Chegaram. Eles tinham a Bíblia, nós tínhamos a terra. Eles nos disseram: "Fechem os olhos e rezem! "Quando abrimos os olhos, eles tinham a terra e nós a Bíblia."

(Desmond Tutu)

"Que evangelho pode a raposa ensinar às galinhas?" (Leonardo Boff)

"Abaixo do Equador não existe pecado, parece que os índios vivem no paraíso terrestre que nem Adão e Eva" (Dito popular europeu do séc. XVI)

Indiscutivelmente, o imaginário utopista-comunista possui uma linha de inspiração 
cristã ao longo de toda a história ocidental dos últimos dois milênios. Tendo raiz no próprio evangelho e no relato da primeira comunidade cristã (para muitos o primeiro grupo comunista a surgir), ela se alimenta duma longa tradição espiritual que vem dos primeiros três séculos de cristianismo, passa pelos Padres do Deserto, pelos Monges e pelos Mendicantes entre os séc. X e XII ${ }^{14}$ e desemboca em Joaquim de Fiori (1145-1202) e sua profecia do iminente advento do Reino. Os ideais franciscanos de pobreza e fraternidade do séc. XIII receberam forte influência joaquiniana, bem como o movimento comunista do fr. Dolcino (1304-1307). Já as primeiras grandes utopias modernas são, não por acaso, de matriz católica: Tomas Morus (1478-1535) que faz parte do cânone dos santos católicos, amigo do frade agostiniano Erasmo (1467-1536), ambos grandes propagadores de uma reforma dentro do catolicismo - e do dominicano Campanela (1568-1639). A revolta dos camponeses alemães, liderada por Tomas Münzer entre 1524 e 1528, também merece figurar entre os precursores cristãos do movimento utópico.

A América deu novo alento à difundida esperança milenarista de um reino de mil anos de felicidade que antecederá o juízo final ${ }^{15}$. Acreditando que o continente perdido de Atlântida teria emergido, ou encontrado o Eldorado, aqui os primeiros navegantes tiveram uma autêntica Visão do Paraíso (Holanda, 1958/1992). Neste momento temos, em verdade, um amálgama entre a cruz e a espada, entre cobiça e devoção, uma fusão de motivos sagrados com profanos que levou a ambição e religião à tingirem-se "das cores da fantasia" (Holanda, 1992: 211). Tanto Colombo, quanto os primeiros missionários, estavam impregnados dos ideais joaquimitas, e acreditavam estar próxima a "última era do mundo". As visões escatológicas se prolongam no séc. XVII graças à Antonio Vieira SJ (1608-97), mestre da retórica barroca, que transformará o sebastianismo português num autêntico milenarismo ${ }^{16}$, vindo a influenciar decisivamente outro também Antonio e barroco, Conselheiro, líder da comunidade de Canudos, já no final do séc. XIX. Mesclando-se com o mito guarani na Terra sem Males, o encantamento milenarista impregnou profundamente o imaginário popular, expressando-se fortemente em Canudos e na Guerra do Contestado, raros momentos em que o povo pobre e mestiço irrompe com voz própria na cena política do Novo Mundo ${ }^{17}$. Ainda hoje, numa verdadeira inspiração

\footnotetext{
${ }^{14}$ Moore Jr. (1999) faz uma excelente discussão sobre a evolução dos ideais comunitários ao longo das gerações, confrontando a experiência monástica dos Monges Cartuxos (fundada por S. Bruno em 1084), da ordem cisterciana (1098) e de mosteiros budistas, com o ascetismo dos quakers e com a experiência sionista socialista dos Kibutz.

15 Fundamentei-me neste tópico sobre milenarismo na magnífica obra de Cohn (1981), bem como em Chauí (1998), Clastres (1978), Delumeau (1998) e Holanda (1992), bem como consultei as advertências que Voegelin (1982) formula às perspectivas políticas milenaristas.

${ }^{16}$ Barboza F. (2000: 345) não tem dúvida em associar o mito sebastianista com a necessidade da monarquia portuguesa, recém restaurada, de lançar "mão de toda a imaginação barroca para a sua legitimação".

17 Os europeus, ao se defrontarem com a América, deslumbram-se, chamando esta região de Novo Mundo, contrapondo-se a velha e decadente Europa.
} 
transcultural, ele anima e perpassa a nossa cultura, como afirma Chauí (1992: 11) avaliando o “mito fundador do Brasil” por ocasião das efemérides dos 500 anos: "É com essa história profética que as classes populares brasileiras têm acesso à política, percebida por elas como embate cósmico entre a luz e a treva, ou entre o bem e o mal, e na qual a questão não é a do poder, mas a da justiça e da felicidade".

As primeiras notícias do novo mundo propiciaram o entroncamento dos elementos utópicos presentes no milenarismo medieval com o espírito renascentista. $\mathrm{O}$ encontro com o mundo americano fertilizou os horizontes utópicos da velha Europa, inspirando decisivamente os grandes filósofos humanistas da renascença (Erasmo, Morus, Montaigne, 1533-92). Estas primeiras utopias da era moderna bebem também nas fantasias provenientes do mundo americano então recém “descoberto”. Há indícios de que o projeto de B. de Las Casas, escrito em 1516, de estabelecer comunidades livres de índios e espanhóis, tenha servido de inspiração para Morus, pois teria sido remetido para Flandres, onde estava o rei Carlos, e, através de Erasmo, então conselheiro real, chega às mãos de Morus ${ }^{18}$. Este escreveu sua famosa obra na semana em que hospedava seu amigo Erasmo. Numa autêntica inter-fecundação entre utopia e realidade, tão logo Morus publica Utopia (também em 1516) - completamente escolástica em seu método de construção, avalia Skinner (1996: 274), ela já influencia práticas utópicas no Novo Mundo, como a de Quiroga, bispo de Michoacán, que tentou implantar a partir de 1530 comunidades inspiradas diretamente em Morus (Ainsa, 1990). "A geografia das utopias situase nas Américas", reivindica Oswald de Andrade (1953/1990: 164). Foram então inúmeros os experimentos utópicos - desde os mais racionalizantes inspirados diretamente em More, aos mais místicos inspirados nas profecias de Joaquim de Fiori (CHIAMPI, 1994: 458) - que buscavam uma "cristandade das Índias" (Dussel).

Exportamos para a Europa o princípio do homem natural e do inconformismo que vai nutrir sua imaginação utópica, levando à Oswald de Andrade (1928/1990: 269), em seu rango antropofágico, sentenciar: "Sem nós a Europa não teria sequer a sua pobre declaração dos direitos do homem". Como assinalaram diversos autores, o (des)encontro com a América possibilitou aos europeus "não apenas novos horizontes mas a possibilidade de confronto, de espelhamento e de experiência do Outro e, por extensão, de si mesmos" (CARVALHAL, 1994: 386). "Menos que um conceito geográfico, (...) a América foi para viajantes, evangelizadores e filósofos uma construção imaginária e simbólica" (CHAUÍ, 2000: 9). Segundo O’Gorman, a América não foi descoberta: foi inventada, porque era necessária à imaginação e ao desejo

\footnotetext{
${ }^{18}$ Esta tese é examinada por Victor Baptiste (conf. Gutiérres, 1995: 99).
} 
europeus, corresponde ao profundo sonho humano de um lugar feliz, de uma Idade do Ouro ${ }^{19}$. Entretanto, ao longo da história da América, a fantasia do paraíso e do bom selvagem coexistiu com o colonialismo e com o trabalho forçado. Os colonizadores anti-utópicos, que negaram aos índios sua condição humana, constituíram a imensa maioria e, se alguns estavam interessados mais na alma, muitos mais queriam era o corpo da índia e o braço escravo do marido dela (GAMBINI, 2000: 175).

Do erasmismo espanhol resultou uma corrente que, transplantada para América, buscou nas novas terras refundar a cristandade ${ }^{20}$. Daí que para o continente americano inicialmente vieram apenas frades, em geral das ordens religiosas mendicantes, que "preconizavam conduta religiosa depurada dos vícios que haviam maculado a Igreja" (Salinas, 1997: 144). Os inúmeros exemplos da rejeição radical do projeto economicista-exploraatório por parte dos missionários, como os do frade dominicano e Bispo de Chiapas, Las Casas, do padre Montesinos, dos franciscanos Bernardino de Sahagún (1499-1590) e Vasco de Quiroga, decorrem, fundamentalmente, dos ensinamentos de Jesus, como o próprio Las Casas na época o disse ${ }^{21}$. Mas, se os missionários não assumiram in toto o projeto colonial, em essência adotaram uma ideologia colonialista - o que, para Todorov (1993: 169) não diminui a grandeza destes personagens - uma vez que um cristianismo das Índias e não nas Índias era sonho dos missionários e não dos índios que não foram consultados (BOFF, 1992: 76). No dizer de Suess (1991: 110), “a fraternidade radical nas Américas, no século XVI, exigiria a luta contra o sistema colonial, exigiria dissidência e ruptura". Além disto, as incômodas vozes proféticas destes padres não podem servir de álibi para o fato de que foram muitos os eclesiásticos que não só toleraram a servidão do índio e a escravidão do negro, como também se beneficiaram delas (SUESS, 1991: 99) ${ }^{22}$. Houveram, em verdade, conflitos ao interior do projeto evangelizador entre os mais ortodoxos dominicanos que queriam uma transformação completa dos novos cristãos, e os mais realistas e pragmáticos franciscanos, que se imporão, os quais se conformam com o presente, mesmo que imperfeito (TODOROV, 1993: 203), daí resultando as práticas de sincretismo.

\footnotetext{
${ }^{19}$ Uma ampla avaliação do debate quanto à constituição utópica da América e das consequências deste tratamento se encontra em Fornet-Betancourt, 1993.

${ }^{20}$ Bataillon (1996: 807-831) e Ureña (1935/1978:110) demostram que muitos ibéricos vindos para a América eram erasmianos e, inclusive, joaquimitas e milenaristas. Sobre esta utopia social cristã do século XVI ver também Ainsa (1990; 1996); Boff (1992); Dussel (1993) e Salinas (1997).

${ }^{21} \mathrm{Na}$ avaliação de Todorov (1993: 189), "é na doutrina cristã " que Las Casas vai fundamentar seu surpreendente perspectivismo "onde cada um é relacionado a seus próprios valores, em vez de ser referido a um ideal único"

${ }^{22}$ A crítica à ideologia missionária também se encontra elaborada por Gambini (do ponto de vista psicanalítico) e Neves (antropológico e histórico).
} 
Entretanto, se o barroco europeu já foi caracterizado como a arte da Contrarreforma ${ }^{23}$, como expressão do estado de alma dos povos católicos após o Concílio de Trento, o barroco latino-americano tem um caráter próprio ${ }^{24}$, sendo retratado por Lezama Lima (1910-1976) como a arte da contra conquista (1957/1988: 80). Diferentemente da outra América (a do Norte, que, desconhecendo o barroco é incapaz de ter outra relação com o indígena que não seja a exclusão), "o barroco deixava espaço para a cultura indígena significar" (THEODORO, 1992: 167). Diante do pesadelo do genocídio que no espaço de um século levou a eliminação de $90 \%$ da população nativa então estimada em 70 milhões, a estratégia barroca ganha ainda mais relevância, indo além da opção entre submissão ou rebeldia: nem se submeter, nem rebelar-se, mas submeter-se e rebelar-se ao mesmo tempo (Echeverría, 1998: 181). Era a eleição de uma terceira alternativa, excluída, "um salto a um terreno histórico diferente" (181). Ao invés do suicídio, "a vida dupla e labiríntica do sincretismo e da dissimulação. O barroco admite a contemporização, ensina artifícios de duplicidade" (BARBOZA FILHO, 2000: $409)^{25}$.

Aponta Octavio Paz, em O labirinto da solidão (1950), que “a diferença das colônias saxônicas é radical", pois enquanto na ibérica pelo batismo católico "os índios, em situação de orfandade, (...) encontravam um lugar no mundo", "esta possibilidade (...) foi desapiedadamente negada aos nativos pelos protestantes da Nova Inglaterra" (PAZ, 1992: 94). Sabendo que tais ideias farão "sorrir qualquer um que conheça a conduta dos colonos para com os indígenas", adenda que é verdade que os índios não foram exterminados porque os europeus precisavam de mão de obra nativa, "mas sem a Igreja o destino dos índios teria sido muito diverso". Aspira Paz compreender a sociedade colonial "como uma totalidade viva e, por isso, contraditória", e não justificá-la: "a rigor, enquanto subsista esta ou aquela forma de opressão, nenhuma sociedade se justifica" (ibid.: 95).

Somos atrasados em que? Em não termos sido eficientes o suficiente no extermínio dos índios como na América do Norte (VELOSO, 1994: 13)? Isto não quer dizer que somos menos cruéis ou mais humanos que outros, pois nosso sistema tem "as mesmas capacidades de criar dilemas e exprimir o lado tétrico e humano dos homens. Mas é uma configuração que revela uma intensa capacidade de relacionar instituições que o Ocidente puritano e anglo-saxão

\footnotetext{
${ }^{23}$ Clássica afirmação de Weisbach em $\boldsymbol{O}$ Barroco, a arte da Contra-Reforma, 1921.

${ }^{24}$ É bom recordar que o barroco artístico americano se estende até o final do século XVIII, 100 anos depois de ter se encerrado na Europa.

${ }^{25}$ A tese da simulação enquanto forma de sobreviver e vencer também é promovida por Bruit (1995). Também Buarque de Holanda, em Raizes do Brasil (1963: cap. 2), acentua os traços da cultura católica que permitiram um terreno de transição para que índios e negros pudessem acomodar-se e mestiçar-se.
} 
separou" (DA MATTA, 1991: 108).

A estética barroca na América é um fenômeno peculiar, envolvendo outros significados. Enquanto o peninsular está marcado pela decadência ibérica, os americanos, embora produzissem trabalhos semelhantes aos europeus, se interrogam pelo futuro, perguntam pelo nosso lugar no mundo: "a quem devíamos lealdade? A nossas mães quíchuas, astecas ou chibchas? A quem deveríamos dirigir as nossas orações? Que idioma íamos falar?" (FUENTES, 2001: 196). A alegoria barroca, ao permitir percepções diversas, a justaposição de significados, possibilita a coincidência de contrários, dissimular o universo das culturas afroameríndias, tornando-se "uma estética capaz de incorporar elementos nativos" (THEODORO, 1991: 166). Entende Theodoro que, ao negar a busca de elementos homogêneos, o barroco "é uma estética da miscigenação". Ao contrário da estética renascentista que reproduz o modelo natural, o barroco "representa a possibilidade de contato entre padrões culturais indígenas e europeus" (ibid.: 126) ${ }^{26}$. É bom recordar que as culturas ameríndias pré-colombianas adotavam figuras que "representavam princípios opostos e que se conciliavam independentemente de um elemento central" (ibid.: 29).

Se o jesuíta Antonio Vieira é considerado um ícone do barroco colonial e metropolitano, para Lezama Lima (1988: 106) e outros a culminância do barroco artístico americano está na obra do mulato Antônio Francisco Lisboa (1730-1814), o Aleijadinho, síntese completa e genial da raça mestiça e da arte mestiçada. Já sua grande expressão literária encontra-se em Soror Juana de la Cruz (1648-95), cujos versos são praticamente um programa filosófico e espiritual: "En dos partes dividida / tengo el alma en confusión: / una esclava a la pasión, / y outra, a la razón medida".

O modo barroco de se apropriar da estética barroca do colonizador "restitui às formas artísticas a sua abertura para veicular ideologias díspares", aprecia Chiampi (1988: 80). Como uma estratégia de sobrevivência, o outro, vencido, mas não aniquilado, não estava em condições de disputar a supremacia. Desse modo, a estratégia da mestiçagem irá preparando a rebelião para o próximo século.

A estratégia barroca é ambígua porque tanto é produto da resistência dos povos americanos nativos ao domínio ibérico, um modo dos indígenas conservarem suas tradições; quanto também pode ser vista simultaneamente como derivada das opções evangelizadoras ou uma manipulação dos missionários. Em muitos dos principais centros de peregrinação religiosa

26 Também a utilização de figuras mestiças saídas diretamente do povo, inclusive com a introdução de santos negros no altar (mesmo não incluídos no cânone oficial), bem como uma arquitetura de igrejas sem cúpulas que expressa uma arte do povo, diferencia o nosso barroco do europeu (Sant'Anna, 1997: 163). 
contemporâneos é quase impossível saber quem é adorado nos altares barrocos, pois os templos cristãos foram simplesmente construídos sobre os altares indígenas das culturas mais avançadas. Este é o caso do maior ponto de romaria das Américas, a basílica de Guadalupe, padroeira do México e mito fundador da identidade mexicana, que simplesmente foi construído no mesmo local onde era adorada a deusa Tonantzin ou mãe de todos os deuses (LAFAYE, 1977). "Com o barroco, o que era apenas tolerado é verdadeiramente epifanizado" (MAFFESOLI, 1996: 208). O forte sincretismo é, certamente, fruto da disputa pelos corações e mentes de populações cada vez mais desesperançadas.

Nem as comunidades utópicas de Las Casas e Quiroga, nem a rara variante de Gonzalo Guerrero $^{27}$ identificando-se completamente à cultura indígena, prevaleceram. É a Malinche ${ }^{28}$, intérprete e amante de Cortez, que é emblemática dos tempos que advirão do encontro entre duas civilizações tão diferentes. Além de ter desempenhado um decisivo papel na conquista do México, adquire um significado especial. Falando a língua nova espanhola, mãe de um filho do conquistador, mãe do primeiro mestiço, do primeiro mexicano, anuncia simbolicamente a mestiçagem das culturas, a mistura em detrimento da pureza, plasmando as bases da nossa civilização multirracial (TODOROV 1993: 98; FUENTES, 2001: 117; DUSSEL, 1993: 52).

Se índios e negros sempre "relutarão em aderir, do fundo do coração, à mensagem cristã" (Boff, 1992: 77), o processo de mestiçagem revela uma estratégia barroca onde nem se busca adotar a figura peninsular da civilização europeia, nem retomar a civilização précolombiana, mas em refazer a civilização europeia agora como uma civilização americana (181), ou melhor, como uma América Barroca (THEODORO, 1992). A estratégia de contra conquista da América é a da conquista dos conquistadores pelos derrotados, levando ao "surgimento de uma sociedade propriamente americana, multirracial e poli cultural". " $O$ sincretismo religioso triunfou e com ele, de algum modo, os conquistadores foram conquistados" (FUENTES, 2001:124,147). Isto já era afirmado por Oswald de Andrade (1990: 270) em 1928 com sua sábia sentença: "Nunca fomos catequizados. Fizemos foi carnaval".

Apesar do seu fracasso histórico, o sonho de uma Igreja das Índias permaneceu. A utopia de Francisco no séc. XIII, que é a de Jesus, retomada com os primeiros missionários em solo americano no séc. XVI, alimenta hoje aqueles que novamente sonham com uma sociedade solidária. Este renascimento do projeto comunitarista duma Igreja dos Pobres - com a

\footnotetext{
${ }^{27}$ Guerrero, após sobreviver à um naufrágio em 1511, se integra ao povo Maia onde se tornou cacique e chefe militar. Morreu em combate contra o exército espanhol liderando guerreiros yucatecas.

${ }^{28}$ Para os brasileiros é Iracema quem cumpre este papel no nosso imaginário.
} 
emergência a partir de 1960 das CEBs (Comunidades Eclesiais de Base), do Conselho Indigenista Missionário, da Comissão Pastoral da Terra e da ação das diversas pastorais - é herdeiro de diversas forças históricas: decorre tanto da tradição romântica anticapitalista, quando da indigenista, bem como da utopia dos primeiros missionários, da emergência do catolicismo social e do laicato na primeira metade do séc. $\mathrm{XX}^{29}$ (confirmada e ampliada pelo Concílio Vaticano II) e da irrupção política dos pobres através dos movimentos sociais e populares (Boff, 1992: 130). Não por acaso, é do seio da renovação teológica latino-americana (a Teologia da Libertação) e dos movimentos sociais que dela brotaram que, na virada do século XX, irá fermentar a Economia Solidária.

Ainda que aqueles religiosos renascentistas tenham sido incapazes de instaurar o reino de Deus na república dos homens, pois prevaleceu o projeto mercantilista-militar, a persistência missionária livrou a população indígena da extinção absoluta. A ação evangelizadora permitiu a continuidade da propriedade comunal indígena ao longo da era colonial até o séc. XIX em vasta área da América hispânica. Zapata, no México, iniciará sua rebelião em nome dos direitos outorgados pela monarquia espanhola e que os regimes republicanos então estavam eliminando em nome da propriedade privada identificada com o progresso (FUENTES, 2001: 135). Em parte decorre daí a sobrevivência das fortes tradições artesanais na AL, o qual em geral se reproduz fortemente ancorado numa comunidade na forma de ofícios que se transmitem de uma geração para outra (CAMARENA, 1997).

Octavio Paz (1984: 30) vislumbra que, mesmo com o tomismo se desvanecendo como filosofia no horizonte intelectual e político do séc. XVIII, na América Ibérica "as atitudes e hábitos que lhes eram consubstanciais tem persistido até nossos dias", modelando não mais como filosofia, mas como "atitude intelectual” a reflexão na América Latina. De alguma forma aqui convergiram o espírito comunitário da matriz católica com a inexistência da propriedade privada e da herança pessoal entre os ameríndios.

Apesar da brutalidade do colonialismo nas terras americanas, a fantasia do mundo novo persistiu em nosso desejo e nosso imaginário, como uma profunda marca de nascimento, nosso mito de origem, como se constata na "nossa América" sonhada por José Martí, "berço de uma nova humanidade"; no chamado a sermos uma "raça cósmica" de José Vasconcelos; ou na promessa de uma "metarraça" de Gilberto Freire. "Fomos fundados pela utopia; a utopia é nosso destino", realça atualmente Fuentes (2001: 126). Após um amplo balanço da formação do Povo Brasileiro (1995), proclama também Darcy Ribeiro (1922-97), possivelmente o

${ }^{29} \mathrm{O}$ tomismo, renovado pelo catolicismo social francês, novamente ressurge no Brasil nas primeiras décadas do séc. XX, indo contagiar uma geração de jovens universitários que irá moldar a teologia da libertação. 
principal antropólogo latino-americano, que somos uma província da civilização ocidental, um nova Roma, "tardia, mas melhor, porque lavada em sangue índio e sangue negro. (...) uma nova civilização, mestiça e tropical" (1995: 265; 447-449). Darcy chega às estas conclusões, nesta sua obra derradeira, após sintetizar sua teoria do processo civilizatório na qual aponta os diversos povos germinais (árabes, eslavos, iberos e anglos) que dão origem às diferentes variantes civilizacionais modernas. Contrasta, então, detidamente, o universo católico e barroco ibérico, com o mundo reformista e gótico das gentes frias e nórdicas, observando que se os nórdicos realizam algumas das potencialidades da civilização ocidental, (...) nós, ao contrário, "somos a promessa de uma nova civilização", pois, como temos "outros modos tomados de mais gentes (...) somos mais ricos de humanidades" (ibid.: 73). Arvora ainda que é nosso papel "ensinar o mundo a viver mais alegre e mais feliz" (ibid.: 265).

Mas, o mais importante neste momento para nossa reflexão é observar que se mantiveram, de algum modo, elementos da economia da dádiva naturalmente praticada pelos povos pré-colombianos. Longe de idealizá-los conforme a mítica imagem do "bom selvagem"30, não resta dúvida de que os indígenas praticavam um sistema econômico completamente distinto dos europeus. O testemunho do próprio Colombo é eloquente, dando início ao mito do "bom selvagem": "Não cobiçam os bens de outrem", anota o almirante em seu diário em 26.12.1492 (apud. TODOROV, 1993: 38). "Não pude saber se possuem bens privados, mas tive a impressão de que todos tinham direitos sobre o que cada um possuía (...) dando tudo o que tinham, como bestas idiotas", escreve em fevereiro-março de 1493 (ibid.). Anota já no primeiro encontro que "tudo aceitavam e davam do que tinham com a maior boa vontade. Mas me pareceu que era gente que não possuía praticamente nada" (COLOMBO, 12.10.1492/1984: 44). Por não entender que estava diante de uma outra lógica econômica não regida pelo afã da riqueza e portadora de uma sapiência muito maior que a europeia em termos de integração com a natureza e de solidariedade inter-geracional (entre outras características destacamos que as sociedades nativas jamais batem nas crianças), o que se constata por exemplo nas habitações indígenas, hoje apontadas como exemplares de adaptação aos trópicos pela corrente permacultural (BRAUN, 2001), Colombo interpreta como própria de estúpidos animais a desconcertante generosidade dos índios, rotulando seu modo de vida como de extrema pobreza, negando assim que pudessem ter um sistema econômico de algum valor (MELIÁ, 1991).

\footnotetext{
${ }^{30}$ Concordamos com Todorov (1993: 250) de que "há alguma leviandade em limitar-se a condenar os maus conquistadores e lamentar pelos bons índios (...)". Por outro lado, como adverte Gebara (2000: 145), "a vítima não se torna virtuosa pelo fato de ser vítima".
} 


\title{
4. A atualidade do barroco.
}

\begin{abstract}
"Não consigo entender por que os políticos norte-americanos são maus quando têm amores com belas mulheres inofensivas, e em compensação são bons quando têm amores com as grandes empresas que vendem armas ou veneno" (Eduardo Galeano)
\end{abstract}

Hoje, o samba, o futebol, a malandragem, a capoeira e a música popular, longe de serem excentricidades, são verdadeiros símbolos da nossa identidade (o que não significa que isto tenha alguma tradução em termos de opções de desenvolvimento que correspondam a mesma). Facilmente podemos vislumbrar as profundas marcas barrocas na cultura brasileira atualmente presentes na umbanda ${ }^{31}$ (mistura das tradições afro-populares com o catolicismo); nas procissões, como a amazônica demonstração de fé do Círio Pascal em Belém do Pará, considerada a maior procissão das Américas (tradição originária do séc. XVIII e que cultua uma imagem de uma virgem morena); e no carnaval, possivelmente sua expressão maior. Também o Santo Daime é uma incrível expressão religiosa destas terras barrocas. Combinando elementos das tradições incaicas, dos povos indígenas amazônicos, da religiosidade afropopular e do catolicismo rústico e caboclo, o Santo Daime hoje se difunde nas camadas médias dos centros urbanos brasileiros, absorvendo elementos da atual contracultura juvenil, se inserindo perfeitamente na onda ecológica e nas redes de comércio justo globais, uma vez que se organiza produtivamente conforme os princípios da ES. De modo geral, a característica gelatinosa e ambígua da ES, aparente mistura de opostos, é típica do ethos barroco da AL, o qual está mais frequentemente registrado na nossa literatura e artes-plásticas, mas diz respeito amplamente à nossa história social.

O barroco continua atual na reflexão filosófica, histórica, sociológica, antropológica e política $^{32}$, sendo especialmente uma realidade viva e atual que nos encanta e confunde, como no impossível futebol das pernas tortas de Garrincha (1933-1983); no cinema de Glauber Rocha (1939-1981) e Zé do Caixão; no teatro de Antônio Nóbrega ou do dramaturgo Nélson Rodrigues (1912-1980); na arte-plástica da mexicana Frida Kahlo (1907-1954), Arthur Bispo do Rosário $(1909-89)^{33}$ ou de Hélio Oiticica; na música de Raul Seixas (1945-89) e Hermeto Pascal; na

\footnotetext{
${ }^{31}$ Ao invés da secularização, observamos, desde os anos 50 do séc. XX, uma impressionante e contínua expansão de religiões populares antípodas - Umbanda e Pentecostalismo - justamente em nossas cidades mais industriais.

${ }^{32}$ Explicitado com vigor nas obras de Barboza Filho, Echeverría, Fuentes, Hoornaert, Lezama Lima, Maffesoli, Morse, R. Sant'Anna, B. Santos, Theodoro.

${ }^{33}$ Ex-marinheiro, ex-lutador de box, teve em 1938 uma visão de Jesus conduzido por 7 anjos azuis. Desde então
} 
poesia de Ariano Suassuna e João Cabral de Melo Neto; na literatura de Jorge Amado (19122001) e Guimarães Rosa (1908-67) ou nos painéis do profeta Gentileza (1917-96) ${ }^{34}$, figuras magnas da cultura brasileira das últimas décadas. Eis que apenas estamos pontuando uma ou duas relevantes expressões contemporâneas por gênero artístico pois, como suspeita Sant'Anna (1997: 202), se fossemos apresentar uma listagem mais completa sobre os exemplos atuais da nossa alma barroca, "seria um não acabar" 35 . O barroco não é meramente mais um dos estilos que produzimos, ele atravessa toda nossa história e revela nosso estilo de vida, "a substância básica de toda uma nova síntese cultural" (SEVCENKO, 1998: 59). "Somos barrocos, e não devemos temer o barroquismo latino-americano", conclui empolgadamente Barboza Filho (2000: 440).

Evidentemente que a generalização ampla do conceito de barroco corre o risco da trivialização e de cair no vazio. Na medida em que apoteoticamente explicar tudo, não significará mais nada e perderá seu valor heurístico. "Convém ser prudente no emprego de um termo tão polissêmico quanto o de barroco", sublinha Maffesoli (1996: 190). Apesar de termos acentuado suas imensas capacidades metafóricas, não se está afirmar aqui um homo barrocus, ou a inexistência de valores e ideologias individualistas no passado e no presente das sociedades latino-americanas, mas sim que nelas ao invés de predominar o caráter individualista e igualitário, como ocorre nas sociedades ocidentais desenvolvidas, encontramos a forte presença das dimensões holísticas e hierárquicas, sendo que o que predomina é a conjunção de ambos caráteres. O que é importante para a compreensão das nossas ambivalentes realidades afroibero-americanas é perceber, como o faz Da Matta (1988: 24), principal antropólogo brasileiro vivo, que somos um caso típico de sociedades que adoraram o código igualitário "sem ter se livrado integralmente de um sistema de valores hierarquizante. A conjugação desses dois códigos" é que dá ao nosso mundo político uma singularidade que faz com que uma "visão pouco crítica venha a enxergar tudo como estando fora de lugar". Ou seja: na AL nenhuma das clássicas categorias de Dumont é exclusiva ou dominante: ambas se encontram presentes

delirou e perambulou pelas ruas do Rio de Janeiro, sendo internado durante 50 anos, dos seus 80 de vida, em colônia para doentes mentais. Após sua morte foi considerado um dos maiores artistas plásticos contemporâneos do Brasil (Hidalgo, 1996).

${ }^{34}$ José da Trino, conhecido como profeta Gentileza, tinha uma vida normal com sua família no Rio de Janeiro como proprietário de uma empresa de caminhões. Em dezembro de 1961 um incêndio num circo matou mais de 400 pessoas, a maioria crianças. Seis dias após, véspera do Natal, ouviu vozes divinas que ordenavam abandonar tudo e se dedicar ao consolo das vítimas da tragédia. Primeiramente instalou-se por anos no local do incêndio, onde consolava todos os que chegavam. Posteriormente, tornou-se andarilho e, após peregrinar pelo Brasil, sempre pregando mensagens ligadas à gentileza, volta ao Rio de Janeiro onde inscreve seus ensinamentos em 55 pilares do viaduto do Gasômetro. Estes "murais" foram restaurados e tombados em 2000 pela Prefeitura da cidade do Rio, como expressão de arte popular (Boff, 1999: 179-184; Guelman, 1997).

35 Sant'Anna (1997: 197) indica também os arquitetos Niemeyer e Lúcio Costa como representativos duma arquitetura que se inspira no barroco. 
dentro das nossas sociedades, mescladas e interagindo profundamente. Nossa ênfase no barroco até este momento quis ser apenas isto: uma ênfase, e não uma afirmação de validade absoluta. O barroco não é nenhum fatalismo cultural, o que seria apenas mais um falso clichê, não "é a linguagem da América Latina, como se houvesse uma só linguagem possível para um mundo que contém tantos mundos" esgrime Galeano (1994: 151). Neste sentido é que empregamos conceitualmente o ethos barroco, apenas enquanto uma categoria englobante apta e fecunda para interpretar sociedades complexas e não lineares dentro de um contexto de transição civilizacional.

Aliás, como a imperfeição é própria do barroco, a burocracia, uma constante das sociedades ibero-americanas, é uma perversa e labiríntica expressão do barroquismo da nossa formação social, como é apontado por muitos críticos (Faoro e Schwartzman) que acentuam as influências negativas da nossa herança patrimonialista ibérica e colonial. Além do mais, é importante registrar que uma outra consequência da matriz barroca, é que nela não se formam sujeitos sociais "à maneira da Europa" (BARBOZA FILHO, 2000: 412). Na interpretação de Da Matta (1991), enquanto nos Estados Unidos a lógica universalista e individualista é predominante, e a cidadania funda-se na homogeneidade de todos os membros tratados igualmente por leis impessoais; entre nós é a relação que transforma o indivíduo em pessoa. Aqui, por contraste, a comunidade é heterogênea, desigual, relacional e inclusiva. "Sua unidade básica não está baseada nos indivíduos-cidadãos, mas em relações e pessoas, famílias e grupos de parentes e amigos". Assim, numa sociedade onde as relações são um elemento central, o favor é básico, estabelecendo "um meio de relacionar pessoas sem extinguir ou ameaçar sua descontinuidade social, mas, ao contrário, reforçando-a". "Num caso o credo diz: iguais, mas separados; noutro ele decreta: diferentes, mas juntos" (ibid.: 115).

Em sua principal obra, Da Matta (1991: 16) suspeita que o "barroco não tenha se esgotado no passado" pois é a "capacidade de relacionar o alto com o baixo, o céu com a terra, o santo com o pecador, o interior com o exterior, o fraco com o poderoso, o humano com o divino, e o passado com o presente" o que nos caracteriza. Da Matta insiste que a capacidade relacional do antigo com o moderno é o que nos tipifica e singulariza. Somos uma sociedade relacional, onde o valor fundamental "é relacionar, misturar, juntar, confundir, conciliar". E isto não é decorrente da fábula da mestiçagem, mas de uma lógica social, de uma mentalidade distinta da que historicamente se configurou nos Estados Unidos. Entende Da Matta que "a especificidade da variante 'católica" " e ibérica, do "mundo da Contrarreforma", reside nas suas múltiplas éticas sociais, contrariamente às sociedades onde o movimento protestante e a revolução industrial se estabeleceram dominantemente (1991: 23-112). Ao responder a 
pergunta o que faz o brasil, Brasil? Conclui que "num mundo que cada vez mais se desencanta consigo mesmo e institui um individualismo sem limites" (1986: 121), esta nossa capacidade de relacionar, de fazer uma "síntese positiva das leis com os amigos" (1991: 140), é de grande valor, pois rompemos com a padronização impessoal-mercantil da moderna vida burocrática, abrindo espaço para valores ligados à alegria, ao futuro e à esperança. Esta síntese criativa entre o indivíduo e suas exigências e direitos fundamentais, com a sociedade e sua ordem pode ser a grande contribuição da nossa sociedade à transição civilizatória contemporânea. Talvez sejamos missionários “dessa possibilidade que já está se esgotando no mundo ocidental”.

Uma das fontes que alimenta o atual avivamento da economia solidária (ES), especialmente seu vetor popular, é a nossa cultura comunitária híbrida, mestiça. A ES permite perceber que nosso legado afro-latino-ameríndio, ao invés de ser um entrave ao nosso desenvolvimento, pode ser um ponto de apoio para sustentar a uma outra modernidade liberta do fetiche de uma falsa riqueza, capaz de reconciliar as imprescindíveis eficácias da ação econômica com a qualidade emancipatória da ação moral.

A existência de um ethos comunitário é imprescindível para que a produção alternativa sobreviva às perturbações do mercado (PIORE; SABEL, 1990: 403). Não há dúvida de que as "novas práticas sociais portadoras de uma nova racionalidade histórica têm um solo mais receptivo e fértil ali onde tramam suas raízes com prévias heranças históricas" (Quijano, 1988: 40). Valle, Souto e Maciel (2002), em uma ampla pesquisa sobre o fenômeno auto gestionário, constatam que "uma forte solidariedade da sociedade local" é um elemento fundamental na sobrevivência do mesmo. Entretanto, como Quijano (1998: 136), assinalamos também que o atual florescimento das atividades econômicas populares e solidárias não decorre simplesmente de uma extensão de um padrão comunitário original, mas responde, e aí reside sua novidade sociológica, tanto às condições atuais em que opera o capital, quanto a uma dinâmica civilizacional mais profunda. As identidades locais não são essências platônicas, mas são historicamente produzidas e tanto sustentam quanto se alimentam da máquina capitalista.

Reconhecemos que a complexidade das sociedades do subcontinente Centro-SulAmericano é imensa, pois, se a herança ibérica nele se mescla com as tradições indígenas e com a cultura das diferentes nações africanas, à elas se misturam progressivamente, especialmente a partir do último quartel do séc. XIX, a cultura dos imigrantes italianos, alemães, japoneses, ucranianos, franceses e etc., sendo que atualmente também se faz sentir a força da sociedade norte-americana. É importante aqui salientar que nas periferias urbanas, exatamente onde emerge o circuito da economia popular solidária, temos a presença de um povo mestiço forjado por todos estes cruzamentos dentro deste imenso caldeirão tropical, onde se origina um povo 
novo em busca do seu destino.

\section{Referências}

AINSA, Fernando. Necesidad de la utopia. Montevideo: Nordan; Buenos Aires: Tupac, 1990. ANDRADE, Oswald de. A utopia antropofágica. São Paulo: Globo, 1990.

BARBOZA FILHO, Rubem. Tradição e artifício: Iberismo e barroco na formação americana. Belo Horizonte: Ed. UFMG; Rio de Janeiro: IUPERJ, 2000.

BATAILlON, Marcel. Erasmo y Espanã. México: Fondo de Cultura Econômica, $2^{\mathrm{a}}$ reimpr. 1996.

BOFF, Leonardo. América Latina: da conquista à nova evangelização. São Paulo: Ática, 1992. . Saber cuidar. Petrópolis: Vozes, 1999.

BORON, Atílio. Prólogo. In: Fernández Retamar, R. Pensamiento de nuestra América. Buenos Aires: CLACSO, 2006.

BRAUDEL, Fernand. O mediterrâneo e o mundo mediterrânico. v. II, SP: Martins Fontes. 1984.

BRUIT, Héctor. Bartolomé de las Casas e a simulação dos vencidos. Campinas: UNICAMP; São Paulo: Iluminuras, 1995.

CARPEAUX, Otto. História da literatura ocidental. Rio de Janeiro: O Cruzeiro, 1960. . Teatro e Estado barroco. Estudos Avançados, v. 4, n. 10, 1990.

CARVALHAL, Tania. O avesso da utopia. In: Meihy, José; Aragão, Maria (org.). América: ficção e utopias. Rio de Janeiro: Expressão e Cultura; São Paulo: EDUSP, 1994.

CHACON, Vamireh. O humanismo ibérico. Lisboa: Imprensa Nacional - Casa da Moeda, 1998.

CHAUÍ, Marilena. Profecias e tempo do fim. In: Novaes, Adauto (org.). A descoberta do homem e do mundo. São Paulo: Companhia das Letras, 1998.

CHIAMPI, Irlemar. O realismo maravilhoso: Forma e ideologia no romance hispanoamericano. São Paulo: Perspectiva, 1980.

CLASTRES, Hélène. Terra sem mal: o profetismo tupi-guarani. São Paulo: Brasiliense, 1978.

COHN, Norman. Na senda do milênio: milenaristas revolucionários e anarquistas místicos na Idade Média. Lisboa: Presença. 1981 
COLOMBO, Cristóvão. Diários da descoberta da América. Porto Alegre: L\&PM, 1984.

DA MATTA, Roberto. O que faz o brasil, Brasil? Rio de Janeiro: Rocco, 1986.

A casa \& a rua. Rio de Janeiro: Guanabara. $4^{\text {a }}$ edição. 1991.

DUSSEL, Enrique. 1492: o encobrimento do outro. Petrópolis: Vozes, 1993. Ética da Libertação. Petrópolis: Vozes, 2000.

. Transmodernidade e interculturalidad. In: Fornet-Betancourt (ed.). Crítica intercultural de la filosofia latinoamericana actual. Madrid: Trotta, 2004.

ECHEVERRÍA, Bolívar. La modernidad de lo barroco. México: Era, 1998.

FORNET-BETANCOURT, Raúl. Problemas atuais da filosofia na hispano-américa. São Leopoldo: Unisinos. 1993.

FUENTES, Carlos. O espelho enterrado. Rio de Janeiro: Rocco, 2001.

GALEANO, Eduardo. Ser como eles. Rio de Janeiro: Revan.1994.

GAMBINI, Roberto. Espelho índio: a formação da alma brasileira. São Paulo: Axis Mundi, 2000 .

GUELMAN, Leonardo. Univvverrsso Gentileza. A gênese de um mito contemporâneo. Rio de Janeiro: Universidade Federal Fluminense - Pontuar, 1997.

GULLAR, F. Barroco, olhar e vertigem. In: Novaes, Adauto ...[et al.]. O olhar. SP: Cia das Letras, 1988.

GUTIÉRREZ, Gustavo. Em busca dos pobres de Jesus Cristo. O pensamento de Bartolomeu de Las Casas. São Paulo: Paulus, 1995.

HIDALGO, Luciana. Arthur Bispo do Rosário. O senhor do labirinto. Rio de Janeiro: Rocco, 1996.

HOLANDA, Sérgio Buarque de. Visão do paraíso. São Paulo: Brasiliense, 5ª ed., 1992.

HOORNAERT, Eduardo. O cristianismo moreno no Brasil. Petrópolis: Vozes, 1991.

HUIZINGA, Johan. Homo ludens. São Paulo: Perspectiva, 4a edição, 1996.

HUNTINGTON, Samuel. O choque de civilizações. Rio de Janeiro: Objetiva,1997.

LAFAYE, Jacques. Quetzalcóatl y Guadalupe. La formación de la consciencia nacional en México. México: Fondo de Cultura Económica, 1977.

LEFORT, Claude. Capitalismo e religião no séc. XVI: o problema de Weber. In: C. Lefort. As formas da história. São Paulo: Brasiliense, 1979. 
LIMA, Lezama. A expressão americana. São Paulo: Brasiliense, 1988.

LIMA, Luís. Teologia de Mercado. Bauru: EDUSC, 2001.

LÖWY, Michel (2000). A guerra dos deuses. Religião e política na América Latina. Petrópolis: Vozes.

MAFFESOLI, Michel. No fundo das aparências. Petrópolis: Vozes, 1996.

Elogio da razão sensível. Petrópolis: Vozes. 1998.

MARAVALL, José A. A cultura do barroco. São Paulo: EDUSP, 1997.

MELIÁ, Bartomeu. Culturas indígenas e evangelização: desafios para uma missão libertadora. In: Suess, P. (org.). Culturas e evangelização. São Paulo: Loyola, 1991.

MIRES, Fernando. El discurso de la indianidad: la cuestión indígena en América Latina. San José: DEI, 1991.

MOORE JR., Barrington. Aspectos morais do crescimento econômico. Rio de Janeiro: Record, 1999.

MORSE, Richard. O espelho de próspero. São Paulo: Cia. das Letras, 1988.

NEVES, Luiz F. Baêta. O combate dos soldados de Cristo na Terra dos Papagaios. Rio de Janeiro: Forense-Universitária, 1978.

OROZCO, Emilio. Manierismo y barroco. Madrid: Catedra, $3^{\mathrm{a}}$ ed., 1981.

PAZ, Octavio Paz. América Latina y la democracia. La tradición antimoderna. In: Summa, n. 212, 1994.

O labirinto da solidão. Rio de Janeiro: Paz e Terra, $3^{\text {a }}$ ed. 1992.

QUIJANO, Aníbal. Notas sobre a questão de identidade e nação no Peru. Estudos Avançados, v. 6, n.16, 1992.

RAMOS, Guerreiro. A redução sociológica. Rio de Janeiro: Tempo Brasileiro, (2. ed.), 1965. RIBEIRO, Darcy. O povo brasileiro. São Paulo: Companhia das Letras, 1995.

ROUANET, Sérgio. Apresentação. In: Benjamin, W. Origem do drama barroco alemão. São Paulo: Brasiliense, 1984.

ROUQUIÉ, Alain. O extremo-ocidente: introdução à América Latina. São Paulo: Edusp, 1991.

SALINAS, Samuel. A Igreja Católica e a conquista espiritual do Novo México. In: Azevedo, F.; Monteiro, J. (org.) Confronto de culturas: conquista, resistência, transformação. Rio de 
Janeiro: Expressão e Cultura; São Paulo: EDUSP, 1997.

SANT'ANNA, Affonso R. Barroco, alma do Brasil. Rio de Janeiro: Comunicação Máxima, 1997.

SANTOS, Boaventura. A crítica da razão indolente. São Paulo: Cortez, 2000.

SCHNEEWIND, J. B. A invenção da autonomia. São Leopoldo: Unisinos, 2001.

SCHUMPETER, Joseph. História da análise econômica. Rio de Janeiro - Lisboa: FCE, 1964.

SILVA FILHO, José C. Moreira. Da 'invasão da América aos sistemas penais de hoje: o discurso da 'inferioridade' latino-americana". In: Wolkmer, A. (org.). Fundamentos de história do direito. Belo Horizonte: Del Rei, $2^{\mathrm{a}}$ ed. , 2002.

SKINNER, Quentin. As fundações do pensamento político moderno. São Paulo: Cia. das Letras, 1996.

SUESS, Paulo. A multiplicidade das vozes na conquista espiritual das américas. In: Sues, P. (org.). Culturas e evangelização. São Paulo: Loyola, 1991.

TAWNEY, R. H. A religião e o surgimento do capitalismo. São Paulo: Perspectiva, 1971.

THEODORO, Janice. América barroca. São Paulo: EDUSP; Rio de Janeiro: Nova Fronteira, 1992.

TODOROV, Tzvetan. A conquista da América. São Paulo: Martins Fontes, $3^{\text {a }}$ reimp., 1993.

UREÑA, Pedro Henriquez. La utopia de America. Caracas: Biblioteca Ayacucho, 1978.

VELOSO, Caetano. Utopia 2. In: Folha de São Paulo, 25.09, caderno 6, 1994.

VENTURA, Roberto. Civilización en los trópicos? In: A. Amarante; F. Garramuõ (org.). Absurdo Brasil. Polémicas en la cultura brasileña. Buenos Aires: Biblos, 2000.

VELHO, Otávio. Besta-Fera: a recriação do mundo. Rio de Janeiro: Relume-Dumará, 1995.

VOEGELIN, Eric. A nova ciência da política. Brasília: UnB, 2a ed. 1982. 